\title{
Bimbingan dan Konseling Karir Remaja "Studi Komparasi SMP IT Abu Bakar dan SMP Taman Dewasa Ibu Pawiatan Yogyakarta"
}

\author{
Ardiansyah \\ Pascasarjana UIN Sunan Kalijaga Yogyakarta \\ ansyah_ardi2828@yahoo.co.id
}

Submitted: 02-03-2018, Revised : 25-05-2018, Accepted : 20-06-2018

\begin{abstract}
The implementation of counseling career counseling of students in SMK IT Abu Bakar Yogyakarta and SMP Taman Dewasa Ibu Pawiatan Yogyakarta in career development towards students shows the difference both in terms of service program of career counseling counseling, or career service orientation toward students. This we can see BK care program services in SMK IT Abu Bakar we are good enough value for the development of students starting with the measurement of talent interest SMP IT Abu Bakar using AMT test equipment in measuring interest in student talent. The guidance of career counseling of SMP IT Abu Bakar is divided into classes for 7 th and 8th grade leading to some extracurricular activities and study club, and for the 9th grade more towards organizing and knowing the next level school that is in high school and various majors in SMA, or even SMK. And as for the career guidance program at SMP Taman Dewasa Ibu pawiatan is BK Career program at SMP Taman Dewasa Ibu Pawiyatan Yogyakarta including daily service program, weekly service, and monthly service. While Pelakasanaan BK Kariri in SMP Taman Marga Pawiyatan more emphasis on cultural and social extra kulikuler development activities and to support the preparation of career class 9, SMP park adult Ms. Pawiyatan career mapping and counseling or the introduction of some secondary or high school level. The concept of BK career in SMP Taman Marga Pawiyatan adult is easier and flexible to solve the problem of the students. The guidance of career counseling submitted by the author in this journal must be a scholarly contribution of academic people in reviewing about the implementation of career counseling guidance in applied in school in order to develop student's career.
\end{abstract}

Keywords: Career Guidance

Abstrak: Pelaksanaan bimbingan konseling karir siswa di SMP IT Abu Bakar Yogyakarta dan SMP Taman Dewasa Ibu pawiatan Yogyakarta dalam pembinaan karir terhadap siswa menunjukan perbedaan baik itu perbedaan dari segi program layananan bimbingan konseling karir, maupun orientasi layanan karir terhadap siswa. Hal ini dapat kita lihat layanan program BK karir di SMP IT Abu Bakar kami nilai cukup baik bagi perkembangan siswa dimulai dengan pengukuran minat bakat SMP IT Abu Bakar menggunakan alat tes AMT dalam mengukur minat bakat siswa. Pengarahan bimbingan konseling karir SMP IT Abu Bakar dibagi tingkatanya untuk kelas 7 dan 8 lebih mengarah beberapa kegiatan ekstrakulikuler dan study club, dan untuk yang kelas 9 lebih kearah keorganisasian dan mengenal sekolah tingkat selanjutnya yakni dalam sekolah tingkat atas dan berbagai jurusan di SMA, atau pun SMK. Dan adapun untuk program bimbingan karir di SMP Taman Dewasa Ibu pawiatan adalah Program BK karir di SMP Taman Dewasa Ibu Pawiyatan Yogyakarta diantaranya program layanan harian, layanan mingguan, dan layanan bulanan. Sedangkan Pelakasanaan BK kariri di SMP taman dewasa Ibu Pawiyatan lebih menekankan pada kegiatan pengembangan ekstra kulikuler kebudayaan dan sosial dan untuk menunjang persiapan karir kelas 9, SMP taman dewasa Ibu pawiyatan mengadakan pemetaan karir dan penyuluhan atau pengenalan beberapa sekolah tingkat selanjutnya atau sekolah menengah atas. Konsep pelaksanaan BK karir di SMP taman dewasa Ibu Pawiyatan ini lebih mudah dan fleksibel untuk mengatasi masalah masalah para siswa. Bimbingan konseling karir yang disampaikan penulis dalam jurnal ini tentunya menjadi sebuah kontribusi keilmuan para insan akademis dalam mengkaji tentang pelaksanaan bimbingan konseling karir yang di terapkan di sekolah dalam rangka mengembangkan karir siswa.

Kata Kunci: Bimbingan Karir

\section{Pendahuluan}

Karier memilki salah satu bagian kedudukan terpenting dalam hidup yang memilki pengaruh penting dalam hidup manusia secara keseluruhan, oleh karena itu ketepatan memilih 
serta menentukan keputusan karier menjadi salah satu tujuan penting terhadap perjalanan kehidup seorang. Keputusan sesorang memilih suatu karir dimulai saat individu berada pada masa remaja. Karena pada usia remaja adalah usia yang dimana, sesorang itu menempuh pendidikan secara formal, yang dimana pendidikan itu di mulai di sekolah, dan sekolah sendiri merupakan aspek penting dalam kehidupan karena pendidikan menyiapkan mereka dalam mengambil keputusan untuk penentuan karir.

Dalam literatur kamus besar bahasa Indonesia pengertian karir terdapat dua pengertian yaitu, pertama, suatu perkembangan dan sebuah kemajuan terhadap keberlangsungan kehidupan, pekerjaan, jabatan dan sebagainya. Kedua, adalah pekerjaan yang membawa harapan untuk maju dan berkembang. Dalam implementasi sering kali terjadi kebingungan dalam menentukan karir yang berujung bada ketidakpuasan indidvidu, oleh karenanya terdapat bimbingan karir dengan orientasi membantu dan mengatasi kebingungan yang dihadapi agar tidak keliru dalam pilihan karir yang dapat merugikannya. Salah satu bentuk dalam bimbingan dan konseling karir ini juga terdapat di sekolah-sekolah.

Seligman(dalam Marliyah, Dewi, \& Suyasa, 2004) karir dapat dikembangkan sejak masa sekolah dan karir dapat juga dikatakan sebagai suatu cita-cita yang diinginkan, baik yang memilki keterkaitan dengan suatu bidang pendidikan, pekerjaan maupun suatu profesi tertentu. Dalam penentuan kareir, seseorang akan mengetahui potensi yang mereak milki, baik itu bakat/minat, kecerdasan maupun tujuan yang akan diiginkan. Pilihan karir merupakan suatu proses atau aktivitas individu dalam usaha mempersiapkan diri untuk memasukkan karir yang berhubungan dengan pekerjaan melalui suatu rangkaian proses kegiatan yang teradarah dan sistematis, sehingga mampu memilih karir sesuai dengan yang diharapkan oleh siswa. Dalam membuat pilihan karir, yakni langakh awal yang harus kita tempuh yakni mencari informasi mengenai berbagai macam alternatif profesi. Dengan adanya alternatif profesi tersebut, membuat sesorang dengan sangat mudah untuk menetapkan pilihan terbaik dalam karirnya.

Sejalan dengan hal itu, berdasarkan pengamatan dan observasi perbandingan yang di lakukan di SMP Taman Dewasa Ibu Pawiyatan, kedua sekolah tersebut berada di bawah dua naungan yayasan pendidik yang berbeda yaitu Yayasan Abu Bakar yang megintegrasikan nilainilai keislaman dan juga yayasan taman siswa dengan pendidikan umum. Kami menemukan perbandingan layanan bimbingan konseling karir antara kedua sekolah tersebut. Adapun dalam jurnal ini akan mencoba menguraikan gambaran dan perbandingan di antara kedua sekolah tersebut. Berdasarkan latar belakang tersebut kami merumuskan rumusan masalah yakni Bagaimana profil bimbingan konseling karir, serta bagaimana layanan bimbingan konseling karir di sekolah SMP IT Abu Bakar Yogyakarta dan SMP Taman Dewasa Ibu Pawiyatan Yogyakarta dalam memberikan proses layanan bimbingan konseling karir terhadap siswa/i dalam menunjang perestasi dan cita-cita peserta didik dalam menentukan masa depan karir siswa. Dalam proses pebandingan ini juga tak terlepas dari tujuan agar dapat melihat profil bimbingan konseling karir dan layanan bimbingan konseling karir dari kedua tempat yang berbeda dalam suatu lokasi yang berada di DI Yogyakarta.

\section{Metode Penelitian}

Penelitian yang digunakan penulis adalah penelitian kualitatif yang lebih dikenal dengan istilah naturalistic inquiry (ingkuiri alamiah)(Moleong, 1994) penelitian kulitatif yakni penelitian yang tidak melakukan perhitungan dengan angka-angka, karena penelitian kualitatif yakni penelitian yang memberikan gambaran tentang kondisi secara faktual dan sitematis mengenai faktor-faktor, bagian-bagian dalam fenomena yang dimiliki untuk melakukan akumulasi dasar-dasarnya saja(Lexy, 1995). Pandangan lain menyatakan bahwa penelitian kualitatif yakni penelitian yang melakukan eksplorasi dan memperkuat prediksi terhadap suatu gejala yang berlaku atas dasar data yang didapatkan di lapangan(Sukardi, 2007). 
Berdasar pada kedua pandangan tersebut, maka penelitian kualitatif dalam penelitian ini dimaksudkan untuk menggali suatu fakta, lalu memberikan penjelasan lalu meberikan pengauatan teori terkait berbagai realita yang ditemukan. Oleh sebab itu, peneliti langsung mengamati peristiwa-peristiwa di lapangan yang berkaitan dengan profil bimbingan konseling karir serta layanan bimbingan konseling karir yang ada diantara kedua sekolah tersebut kemudian membandingkan kedua program tersebut terkait dengan pelaksanaan bimbingan konseling karir.

Subyek dan objek adalah orang yang merespon atau memberi jawaban terhadap pertanyaan-pertanyaan yang disampaikan peneliti. Dalam penelitian ini yang dijadikan subyek penelitian atau sumber data penelitian adalah guru dan siswa yang ada di kedua sekolah tersebut. Adapun yang dijadikan objek dalam penelitian ini adalah profil bimbingan karir, serta program bimbingan karir yang ada di sekolah tersebut. Sumber data yang kami peroleh dapat melalui observasi, dokumentasi dan wawancara langsung kepada guru yang ada di antara kedua sekolah tersebut mengenai program bimbingan konseling yang ada di sekolah.

\section{Hasil Dan Pembahasan}

a. Profil Sekolah

I. SMP Islam Terpadu Abu Bakar Yogyakarta

1. Data Sekolah

Nama Sekolah

Nomor Identitas Sekolah

Nomor Statistik Sekolah

Alamat Sekolah

Kecamatan

Kabupaten/Kota

Propinsi

Kode Pos

Nomor Telepon \&Faks
: SMP IT Abu Bakar

: 200590

: 20403317

: J1 Veteran Gg Bekisar No 716 Q

: Umbulharjo

: Kota Yogyakarta

: Daerah Istimewa Yogyakarta

: 55161

: 0294$) 419134$

2. Visi

Melahirkan Generasi Muslim yang Berpribadi Qur'ani, Berwawasan lingkungan, Unggul dalam bahasa, ilmu pengetahuan dan teknologi.

3. Misi

a. Meningkatkan kualitas pembelajaran Ulumul Qur'an

b. Menyelenggarakan Program pembinaan pribadi Qur'ani secara intensif

c. Menanamkan rasa cinta tanah air

d. Menumbuhkan lingkungan pendidikan yang aman, nyaman, asri dan islami

e. Meningkatkan program pembinaan dan pembiasaan berbahasa arab dan inggris

f. Melaksanakan pembelajaran secara efektif dan berkualitas

4. Tujuan Pendidikan

a. Mempunyai akidah yang lurus dan mampu beribadah secara lurus

b. Hafal 2 jus $(30,29)$ dan bagi lulusan SDIT menambah hafalan minimal 2 jus Al-Quran dalam program regular

c. Hafal minimal 7 jus Al-Quran dalam program takhasus

d. Mampu membaca Al-Quran dengan tartil

e. Mampu menerjemahkan Al-Quran jus 30

f. Mampu bersikap santun dan berakhlak mulia

g. Mampu menjadi pribadi mandiri dan berbakti untuk negri

h. Mampu menjadi pribadi yang peduli dan bertanggung jawab terhadap lingkungan 
i. Mampu memahami teks bahasa Arab dengan baik

j. Mampu mencapai nilai TOEFL minimal 450

k. Setiap siswa meraih mampu meraih rata-rata nilai ujian nasional (UN) minimal 75

1. Berprestasi dalam lomba-lomba dalam tingkat kota provinsi

5. Predo (motto)

Membimbing sepenuh hati agar shaleh dan berprestasi

6. Profil Lulusan

a. Mempunyai akidah yang lurus, ibadah yang benar, dan berakhlak mulia

b. Mempunyai pemahaman islam yang syamil

c. Lulus ujian akhir nasional (UN) dengan prestasi akademik minimal75

d. Menguasai program dasar computer teknologi informasi

e. Mampu berbahasa arab dan inggris

f. Mempnyai hafalan minimal 2 juz Al-Quran pada program regular dan minimal 7 jus pada program thahasus

g. Mandiri, kreatif dan mempunyai jiwa kepemimpinan

\section{SMP Taman Dewasa Ibu Pawiyatan}

\begin{tabular}{lll}
\hline $\mathbf{1}$ & Nama Sekolah & SMP TAMAN DEWASA IBU PAWIATAN YOGYAKARTA \\
\hline 2 & Nama Yayasan & Majelis Ibu Pawiatan Taman Siswa \\
3 & Tahun Pendirian & 1924 \\
4 & Status & Akreditasi " A " Nomor SK: 21.01/BAP-SM/XII/2013 \\
5 & Alamat & Jl. Taman Siswa No.25 F, Kelurahan Wirogunan, Kecamatan \\
& & Mergansang, Kota Yogyakarta, DIY \\
& Kode POS & 55151 \\
& Nomer Telpon & (0274)374290 \\
& E-mail/ Website & TDIP Jogja @ hotmail.co.id \\
& NSS & 2020 460 12 067 \\
& NDS & 200 405 009 \\
NPSN & 20403250 \\
Nama Kepala & KI Drs. Budi Angkoso \\
& Sekolah & \\
NPANIK & 4231 \\
& Tempat Tanggal & Temanggung 07 Januari 1963 \\
Lahir & Pendidikan & Sarjana (S 1) \\
& Tertinggi & \\
Program/ Jurusan & FKIP/FSP \\
Nama & Ketua & Ki Budi Sudarmasto, SH \\
Komite & Pendidikan & Sarjana (S 1) \\
Tertinggi & Program/ Jurusan & Hukum \\
Tipe Sekolah & Sekolah Potensial \\
Rekening Bank & BPD DIY Cabang Senopati. Nomer Rek. : 006.221.024.106 \\
\hline & &
\end{tabular}

Struktur Organisasi SMP Taman Dewasa Ibu Pawiatan Yogyakarta

\begin{tabular}{llll}
\hline No & Nama Pamong (Ki, Nyi, Ni) & Jabatan & Tugas \\
\hline
\end{tabular}




\begin{tabular}{llcl}
\hline 1 & Drs. Budi Angkoso & Guru & Kepala Sekolah \\
2 & Dra. Entam Noorsanty & Guru & Wakasek Kesiswaan \\
3 & Gunawan, S.Pd & Guru & UR. Kesiswaan \\
4 & Ir. Sri Yudi astuti & Guru & 1. Kepala Lab. IPA/ Bendahara BOS \\
5 & Eni Lestari, S.Pd & Guru & Bendahara Bosda \\
6 & Mujilah & Pelaksana TU & Kepala Tata Usaha \\
7 & Sumartuti & Pelaksana TU & Bendahara Sekolah \\
\hline
\end{tabular}

1. Visi

"Berperestasi dalam Iptek, Terkemuka dalam seni Budaya dan Luhur dalam Budi Pekerti"

2. Misi

Dalam upaya mewujudkan visi SMP Taman Dewasa Ibu Pawiatan Yogyakarta menjabarkan misi sebagai berikut:

a. Melaksanakan kegiatan pembelajaran yang efektif, efisien dan terukur untuk mewujudkan perestasi di bidang Ilmu Penegetahuan dan Teknologi.

b. Menyelenggarakan Pendidikan Kesenian dan Penanaman nilai-nilai budaya bangsa untuk mencapai pendidikan yang berbasis seni budaya

c. Mengembangkan dan menerapkan "Among Sistem" dalam pendidikan dan pembelajaran dalam pelaksanaan penerapan pendidikan budi pekerti luhur.

3. Tujuan

Untuk mencapai visi dan misi yang diterapkan SMP Taman Dewasa Ibu Pawiatan dan mewujudkan tujuan pendidikan Nasional yang termuat dalam peraturan pemerintah Republik Indonesia nomer 19 Tahun 2005 Standar Nasional Pendidikan Nasional merumuskan tujuan yang akan dicapai dalam penyeleggaraan SMP Taman Dewasa Ibu Pawiatan sebagai berikut :

a. Meningkatkan mutu pembelajaran dengan menigkatkan kemampuan tenaga kependidikan dan guru baik kompetensi akademik maupun profesionalismenya yang diharapkan pada gilirannnya mapu meningkatkan prestasi belajar siswa.

b. Memenuhi 8 (Delapan) Standar Nasional Pendidikan secara bertahap dengan tekanan melengkapi sarana dan prasarana pendidikan, tersedianya biaya oprasional yang memadai, serta membuka peluang peran serta masyarakat secara optimal.

c. Implementasi secara integral nilai-nilai budi pekerti luhur dan konsep-konsep ketamansiswaan dalam pembelajaran dan pendidikan.

d. Menyiapkan peserta didik dengan bekal yang cukup untuk melanjutkan pendidikan ke jenjang yang lebih tinggi.

Program BK Karir

1. Sekolah SMP IT Abu Bakar

a. Strutur Organisasi Bimbingan Konseling di SMP IT Abu Bakar meliputi,

Koordinator BK

: Suwi Wahyu Utami, S.Pd.

Litbang Dan Humas BK : Ma'ruf, S.Pd

Guru BK Kelas VII

: Kumbang Sigit, S.Psi.

Guru BK Kelas VIII

: Suwi Wahyu Utami, S.Pd.

Suwi Wahyu Utami, S.Pd. : Kumbang Sigit, S.Psi.

b. Ruang BK

Terdapat tiga ruang BK di Sekolah SMP IT Abu Bakar yang terdiri dari ruang konseling individu, ruang tamu, dan ruang guru BK. Fasilitas di ruang BK di setiap ruang terdapat ada beberapa meja, kursi, fas bunga terkecuali dispenser yang tepatnya berada di ruang 
tamu, dengan adanya fasilitas yang seperti itu membuat konselor dan konseling samasama merasa nyaman ketika berkonsultasi.

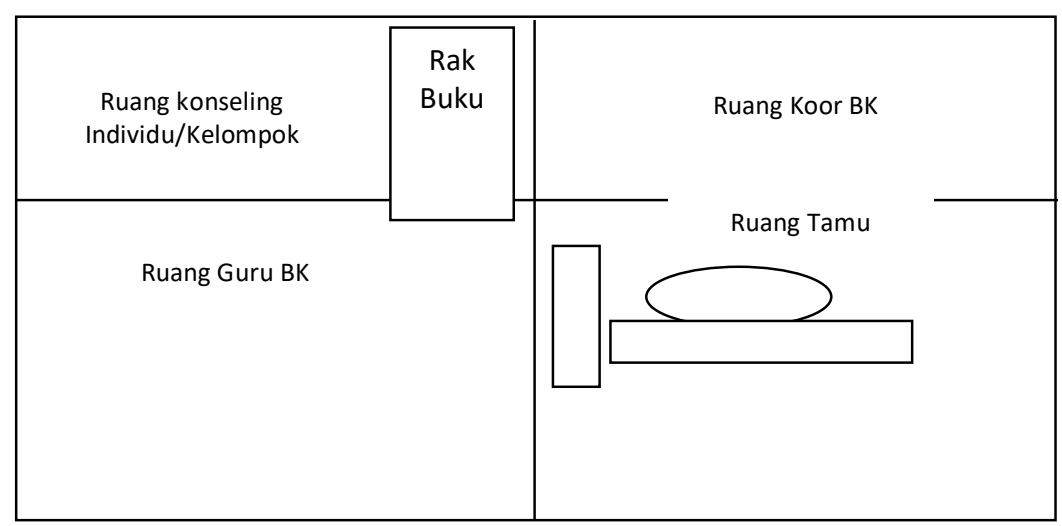

Gambar 1. Ruang BK SMP IT Abu Bakar

c. Program BK

Program BK di SMP IT Abu bakar di antaranya adalah

1. Bimbingan Individu

Bimbingan Individu di SMP IT Abu bakar bersifat konsisional, dan bimbingan dilaksanakan baik bisa dikelas maupun di ruangan BK, masalah yang sering ditangani oleh guru BK di SMP IT Abu Bakar lebih mengarah ke masalah masalah yang bersifat ringan.

2. Bimbingan Kelompok

Bimbingan kelompok yang dilaksanakan di SMP IT Abu Bakar dilaksanakan di ruangan BK dan di ruang kelas, kegiatan ini dilakukan dalam rangka pengembangan informasi kepada peserta didik. Kegiatan ini dailakukan rentang waktunya kondisional.

3. Bimbingan Klasikal

Adapun bimbingan klasikal yang ada di SMP IT Abu bakar adalah sebuah layanan bimbingan dirancang seorang konselor dalam pembinaan karir dengan kontak langsung dengan siswa, bak itu terjadwal baik itu berupa curahan pendapat maupun dengar pendapat mengenai karir yang akan diminati siswa.

4. Bimbingan Karir

Bimbingan Karir yang ada di SMP IT Abu bakar ini bertujuan untuk melakukan pembimbingan kepada siswa mengenai karir yang dinginkan serta mengarahkannya kepada apa yang diinginkan agar karirnya dapat tercapai melalui bimbingan guru BK baik di ruang konseling maupun di runag kelas.

d. Pelaksanaan program karir

Berdasarkan wawancara dengan Bu Sui, Guru BK SMP IT Abu Bakar, Pada tanggal 25 September 2017Pelaksanaan program BK Karir di SMP IT Abu Bakar kami nilai cukup baik bagi perkembangan siswa dimulai dengan pengukuran minat bakat SMP IT Abu Bakar menggunakan alat tes AMT untuk mengukur minat bakat siswa. Pengarahan 
bimbingan konseling kariri di SMP IT Abu Bakar dibagi tingkatanya untuk kelas 7 dan 8 lebih mengarah beberapa kegiatan ekstrakulikuler dan study club, dan untuk yang kelas 9 lebih kearah keorganisasian dan mengenal sekolah tingkat selanjutnya yakni sekolah menengah atas dan berbagai jurusan yang berada di SMA, ataupun SMK.

Berdasarkan wawancara dengan Bu Sui, Guru BK SMP IT Abu Bakar, Pada tanggal 25 September 2017 dikarenanakan ini bimbingan karir pada Siswa tingkat sekolah menengah pertama jadi pengembangan siswa lebih cenderung kepada pengembangan Ekstrakulikuler dan study club agar minat dan bakat para siswa berkembang. Adapun beberapa Study Club yakni, Karya Ilmiah Remaja, kemampuan bahasa, dan tilawatil Qur'an, selanjutnya yakni beberapa ekstra kulikuler yang ada di SMP IT Abu bakar seperti pramuka, berbagai cabang olah raga, fotografi, jurnalistik, dan tari. Secara rinci kegiatan extrakurikuler diuraikan sebagai berikut:

1. Kepaduan (Pramuka SIT )

Adalah kegiatan ekstra wajib yang harus diikuti oleh siswa pada jenjang tertentu sebagai sarana latihan siswa agar memiliki keterampilan hidup, berjiwa disiplin, mandiri, dan mampu survive dalam menghadapi kehidupan.

2. Beladiri

Adalah program ekstra wajib yang harus diikuti oleh seluruh siswa putra kelas VII dan pilihan bagi siswa yang bertujuan agar siswa memiliki kepercayaan diri, kekuatan fisik dan mental, kemampuan melindungi diri dan sebagai sarana tarbiyah jassadiyah siswa sebagai sarana untuk pengabdian kepada Allah SWT. Untuk kegiatan extrakulikuler beladiri yang diterapkan d SMPIT Abubakar adalah Beladiri karate INKAI yang baik dalam segala sesuatunya mengacu pada ketentuan karate Inkai propinsi DIY baik dalam kegiatan latihan, kurikulum pengembangannya dan ketentuan-ketentuan lainnya.

3. Qur'an dan Tahfiz h Al-Qur'an

Adalah kegiatan ekstra wajib yang bertujuan memperbaiki kualitas bacaan dan hafalan al-qur'an siswa. Kegiatan ini wajib diikuti oleh semua siswa yang belum baik bacaan dan hafalan Al-qur'an yang sampai dinyatakan lulus. Siswa yang mengikuti extra Al-qur'an tidak diperkenankan mengikuti kegiatan extra pilihan dan extra wajib yang lain dengan mendapat rkomendasi dari pembina ekstra wajib.

4. Karya Ilmiah Remaja

Adalah kegiatan ekstra yang sifatnya pilihan, sebagai sarana bagi siswa yang mempunyai keinginan unntuk menemukan hal-hal yang baru serta sebagai sarana pembelajaran cara befkir ilmiah dn kreatifitas siswa.

5. Jurnalistik

Adalah kegiatan ekstra yang bersifat pilihan, sebagai sarana bagi siswa untuk menyalurkan hobby/bakat atau menulis sebagai sarana bagi siswa yang mempunyai cita-cita menjadi seorang jurnalis.

6. English Speaking Club

Adalah extra yang bersifat pilihan sebagai sarana bagi siswa untuk mengasah kemampuan berbahasa inggris agar mempunyai kemahiran dalam berbahasa Inggris dengan baik:

7. BSMR (Bulan Sabit Merah Remaja)

Adalah extra yang bersifat pilihan untuk semua siswa dalam bidang kesehatan. Selain itu kegiatan ini juga sebagai sarana untuk membiasakan pola hidup bersih dan sehat.

8. Sport Club 
Adalah kegiatan extra yang bersifat pilihan sebagai sarana mengembangkan kemampuan dibidang olahraga seperti sepak bola, basket, badminton, dan panahan yang diminati siswa agar bakat siswa tersalurkan dengan baik.

9. Elektronika

Adalah kegiatan extra yang bersifat pilihan sebagai sarana mengembangkan kemampuan dibidang elektronika.

10. Komunitas Bakat Minat

Kegiatan ini adalah berupa kelompok-kelompok siswa yang memiliki permintaan tertentu, namun belum terwadah dalam kegiatan ekstrakulikuler. Kegiatan ini diikuti oleh minimal 10 siswa dngan mengajukan proposal pembentukan komunitas. Syarat dan ketentuan dijelaskan dalam Standar Prosedur Operasional Kegiatan kesiswaan. Adapun beberapa kegaiatan SMP IT abu bakar yang berorientasi keluar kelas yakni

\section{Field Study}

Field study (belajar dilapangan dengan obyek belajaryang mendidik dan bervariatif) merupakan kegiatan siswa yang dilakukan dengan bertujuan untuk melengkapi pengetahuan dan keterampilan yang didapatkan dikelas. Kegiatan field study dapat berupa pengamatan, percobaan atau dapat bervariasi sesuai dengan teman, setiap kali pelaksanaan field study dapat mengintergrasikan beberapa macam pelajaran.

2. Out bound

Out bound adalah kegiatan siswa yang dilakukan diluar sekolah dengan tujuan untuk melatih siswa agar mempunyai jiwa kepemimpinan, kemandirian dan kecerdasan emosi, disamping sebagai sarana membangun ukhuwah antar sesama siswa dan sarana refresing. Kegiatan ini bersifat wajib untuk seluruh siswa. Kegiatan ini dapat dilakukan didalam kota maupun luar kota.

3. Study Tour

Kegiatan study tour di selenggarakan sekali selama siswa menempuh Pendidikan di SMP Islam Terpadu Abu Bakar Yogyakarta. Kegiatan ini di lakukan sebagai wahana bagi siswa untuk meningkatkan wawasan dan pengalamannya sekaligus sebagai bekal siswa untuk menyusun pembuatan laporan atau tugas akhir sekolah. Adapun pelaksanaan kegiatan ini dapat dilakukan dalam maupun diluar kota Yogyakarta.

4. Bakti Sosial (Kuliah Kerja Dakwah )

Kegiatan ini bertujuan untuk mengasah kecerdasan emosional dan membangun kepedulian sosial. Program ini biasanya dilaksankan setiap bulan Dzulhijah (bertepatan dengan Idul Adha dan hari Tasyrik).

2. SMP Taman Dewasa Ibu Pawiyatan

\section{a. Ruang BK}

Terdapat satu ruangan yang begitu luas akan tetapi ruangan itu di bagi menjadi 3 bagian, bagian yang pertama di jadikan sebagai ruang tamu, kamar kecil sebagai UKS dan ruang yang satu lagi sebagai tempat konseling. 


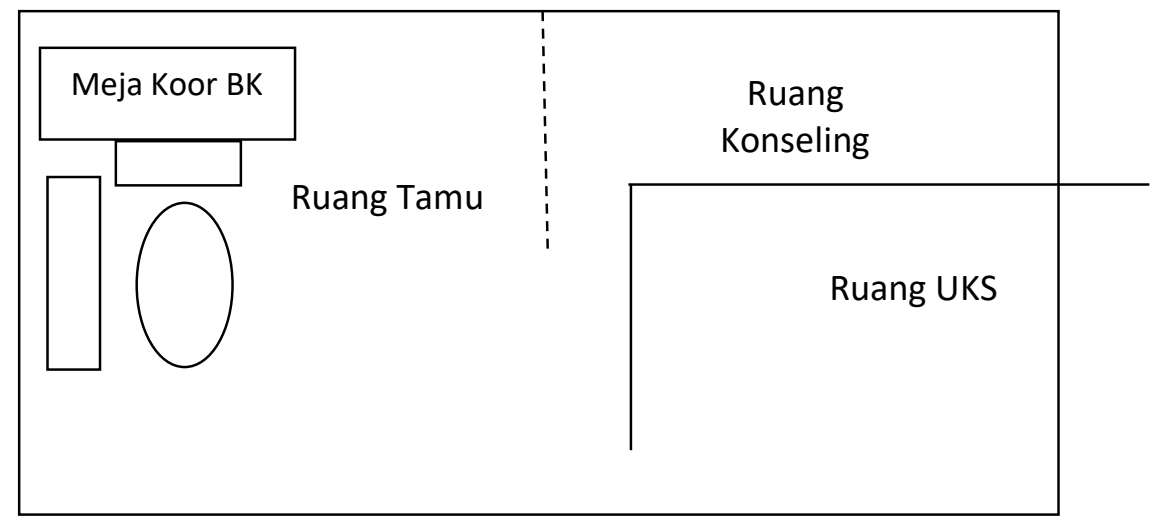

Gambar 2. Ruangan BK SMP Taman Dewasa Ibu Pawiyatan

b. Program BK Karir

Program BK karir di SMP Taman Dewasa Ibu Pawiyatan diantaranya program harian, mingguan, dan bulanan. Untuk program harian sulit terperinci, terbatas dalam pelaksanaannya. Program mingguan yakni ekstrakulikuler yang terdiri dari ektrakulikuler wajib untuk siswa laki-laki pencak silat dan untuk wajib untuk perempuan yakni tari. Selain itu, ektrakulikuler pilihan lainnya yaitu paduan suara dan gamelan. Adapula program minat bakat dengan memberikan dasar-dasar motivasi karir, seperti pelatihan bisnis online dan praktek kuliner.

c. Pelaksanaan BK karir

Berdasarkan wawancara dengan Pak tri, Guru BK SMP taman dewasa Ibu Pawiyatan. Pada Tanggal 03 Desember 17Pelakasanaan BK kariri di SMP taman dewasa Ibu Pawiyatan lebih menekankan pada kegiatan pengembangan ekstra kulikuler kebudayaan dan sosial dan untuk menunjang persiapan karir kelas 9, SMP taman dewasa Ibu pawiyatan mengadakan pemetaan karir dan penyuluhan atau pengenalan beberapa sekolah tingkat selanjutnya atau sekolah menengah atas, konsep pelaksanaan BK karir di SMP taman dewasa Ibu Pawiyatan ini lebih mudah dan fleksibel untuk mengatasi masalah masalah para siswa.

\section{KONSEP LAYANAN BIMBINGAN KONSELING KARIR}

Nama Sekolah : SMP Taman Dewasa Ibu Pawiyatan Taman Siswa Yogyakarta

Kelas/Semester : VIII b

Tahun Pelajaran : 2017/2018 
a. Teori Ginzberg, dkk

Dalam tugas perkembangan, Ginzberg membagi perkembangan karir menjadi tiga periode umum, yaitu:

1. Masa Fantasi (usia 10-12 tahun)

Pemilihan karir masih bersifat asal pilih tidak didasarkan pada pertimbangan tentang kenyataan, tetapi didasarkan pada kesan atau khayalan.

a. Masa Tentatif (usia 11-18 tahun)

\begin{tabular}{|c|c|c|}
\hline 1. & Topik Permasalahan & Merencanakan Minat dan Bakat \\
\hline 2. & Bidang Bimbingan & Karir \\
\hline 3. & Jenis Layanan & Layanan Informasi \\
\hline 4. & Fungsi Layanan & Pemahaman \\
\hline \multirow[t]{2}{*}{5.} & Tujuan & $\begin{array}{l}\text { 1) Siswa dapat mengetahui minat } \\
\text { dan bakatnya }\end{array}$ \\
\hline & & $\begin{array}{l}\text { 2) Siswa termotivasi untuk } \\
\text { mengeksplor minat dan } \\
\text { bakatnya }\end{array}$ \\
\hline 6. & Sasaran & Siswa kelas VII/VIII/IX \\
\hline 7. & Bentuk Layanan & $\begin{array}{l}\text { 1) Training } \\
\text { 2) Membuat papan impian }\end{array}$ \\
\hline
\end{tabular}

\begin{tabular}{lll}
\hline 8. & Uraian Kegiatan & Terlampir \\
\hline 9. & Tempat Pelaksanaan & Ruang kelas \\
\hline 10. & Waktu & Kondisional \\
\hline 11. & Pihak yang Terlibat & Pembimbing dan siswa \\
\hline 12. & Alat & Proyektor, laptop, kertas, speaker, dll
\end{tabular}

dibagi menjadi empat tahap: 1) tahap berdasarkan minat 2) tahap berdasarkan kapasitas 3) tahap berdasarkan nilai 4) tahap dalam masa transisi.

b. Masa Realistis

Yaitu anak mulai bekerja: ada tahap eksplorasi, tahap kristalisasi, tahap spesifikasi

Pada umumnya tahapan perkembangan berlangsung sebagai berikut: pertama, sosialisasi dan identifikasi pilihan berdasar potensi. Kedua, tahapan pemilihan berdasarkan kemampuan dan kapasitas diri. Tahap ketiga yautu tahap realistis, dimana perencanaan dan pemilihan karir dibuat dari pertimbangan yang objektif dan realistik(Rahma, 2010).

b. Pengertian Bimbingan Karir

Bimbingan merupakan suatu proses, yang berkesinambungan, bukan kegiatan seketika atau kebetulan. Bimbingan merupakan serangkaian tahapan kegiatan secara sistematis dan terarah(Yusuf LN \& Nurihsan, 2010). Sedangkan pengertian karir menurut kamus besar bahasa indonesia adalah perkembagan dan kemajuan dalam kehidupan,pekerjaan, jabatan, dan sebagainya, yang diharapkan dapat memberikan dorongan atau semangat untuk maju. Menurut Dalil S, pengertian karir adalah proses yang dengan sengaja diciptakan perusahaan agar karyawan dapat membantu dan berpartisipasi di tempatnya bekerja(Dalil, 2002). Bimbingan karir merupakan langakh pemberian bantuan kepada siswa dalam pemenuhan karir siswa. Sedangakan menurut Nurihsan bimbingan karir merupakan pelayanan bimbangan unuk member bantuan peserta didik mengenal dan memahami dirinya, menenal 
dunia kerja, dan mengembangkan karirnya sesuai dengan yang diharapkan sehingga dapat mewujudkan dirinya secara bermakna(Nursalim, 2010).

Sedangkan pengertian lain bimbingan karir adalah proses pemberain bantuan untuk mempersiapkan dan membekali diri dalam memasuki dunia kerja supaya siap menjangkau jabatan yang diinginkan agar bisa berdaptasi dengan pekerjaan(Winkel, 1997). Bimbingan karir yakni pemberian bimbingan untuk membantu individu dalam perencanaan, pengembangan, dan menyelesaikan masalah-masalah karir, misalnya pemahaman terhadap yugas-tugas kerja dan jabatan, pemahaman pada kondisi dan kemampuan diri, pemahaman kondisi lingkungan kerja, perencanaan dan pengembangan karir, penyesuaian diri di pekerjaan, dan penyelesaian masalah karir yang dihadapi.

Di sisi lain, bimbingan karir juga merupakan sarana pemenuhan kebutuhan demi meningkatkan kemampuan kognitif, afektif, ataupun mewujudkan konsep diri yang positif pada proses pengambilan keinginan, dan ilmu serta skil yang dapat membantu siswa memasuki sistem kehidupan sosial-budaya yang terus menerus berubah(Nurihsan, 2011).

c. Bidang Layanan

Bidang bimbingan karir yang membantu siswa dalam merencanakan dan mengembangkan masa depan karir adalah sebagai berikut:

a. Pemantapan pemahaman diri berkenaan dengan kecenderungan karir yang hendak dikembangkan.

b. Pemantapan orientasi dan informasi karir pada umumnya khususnya karir yang telah dikembangkan.

c. Orientasi dan informasi terhadap dunia kerja dan usaha memperoleh penghasilan untuk memenuhi kebutuhan hidup.

d. Orientasi dan informasi terhadap pendidikan yang lebih tinggi, khusunya sesuai dengan karir yang hendak dikembangkan.

Ada beberapa macam layanan dalam bimbingan dan konseling salah satunya yaitu layanan orientasi, layanan informasi, layanan penempatan dan penyaluran, layanan bimbingan belajar, layanan. konseling perseorangan, layanan bimbingan kelompok, dan layanan konseling kelompok. Namun dalam hal ini, dari beberapa bidang layanan bimbingan dan konseling hanya akan dijelaskan secara rinci beberapa diantaranya saja.

Pelayanan bimbingan dan konseling meliputi berbagai layanan dan kegiatan penunjang yang semuanya itu hendaknya dilakukan konselor sekolah dengan sejumlah lembaga yang menjadi tangung jawab penuh konselor sebagai sasaran layanan. Layanan orientasi mengacu pada diperkenalkanya konseli kepada lingkungan yang baru dimasukannya. Dengan program orientasi itu pada proses penyesuaian diri individu kepada lingkungan biasanya akan lebih cepat sehingga ia dapat lebih cepat dalam menjalani perkembangan dan kehidupannya di lingkungan yang baru itu secara optimal(Prayitno, 2008).

Layanan informasi yaitu layanan bimbingan yang memungkinkan peserta didik dan pihak yang lain dapat memberikan pengaruh yang besar kepada peserta didik dalam menerima dan memahami informasi yang dapat digunakan sebagai bahan pertimbangan dan pengambilan keputusan sehari-hari sebagai pelajar anggota keluarga dan masyarakat. Materi layanan informasi menyagkut:

a. Tugas-tugas perkembangan masa remaja tentang kemampuan dan pengembangan pribadi.

b. Usaha yang dapat dilakukan dalam mengenal bakat, minat, serta bentuk-bentuk penyaluran dan pengembangannya.

c. Tata tertib sekolah, cara bertingkah laku, tata karma, dan sopan santun.

d. Nilai-nilai sosial, adat istiadat, dan upaya yang berlaku dan berkembang di masyarakat. 
e. Mata pelajaran dan pengembangannya seperti program inti, program khusus, dan program tambahan.

f. Sistem penjurusan, kenaikan kelas, syarat-syarat mengikuti ujian.

g. Fasilitas penunjang dalam belajar.

h. Cara mempersiapkan diri dan belajar di sekolah.

i. Syarat-syarat memasuki suatu jabatan, kondisi karir serta prospeknya.

j. Langkah-langkah yang perlu ditempuh guna menetapkan karir.

k. Memasuki perguruan tinggi sejalan dengan cita-cita karir.

1. Pelaksanaan pelayanan bantuan untuk masalah pribadi, sosial, belajar, dan karir.

Layanan penempatan dan penyaluran merupakan bimbingan yang memungkinkan peserta didik memperoleh penempatan dan penyaluran yang tepat yang bisa berlangsung di dalam kelas, kelompok belajar, jurusan atau program studi, program pilihan, magag, kegiatan ekstrakulikuler sesuai dengan potensi, minat, dan bakat serta kondisi pribadi.

Adapun kegiaan layanan penempatan dan penyaluran pada bimbingan dan konseling karir meliputi(Sukardi, 2000):

a. Penempatan kelas siswa, program studi atau jurusan dan pilihan ekstrakulikuler yang dapat menunjang pengembanan sikap, kemampuan, bakat, dan minat.

b. Penempatan dan penyaluran dalam kelompok sebaya, kelompok belajar, dan organisasi kesiswaan serta kegiatan sosial sekolah.

c. Membantu dalam kegiatan program khusus sesuai dengan kebutuhan siswa, baik pengajaran perbaikan maupun program pengayaan dan seleksi masuk perguruan tinggi melalui jalur PMDK, UMPTN.

d. Menempakan dan menyalurkan siswa pada kelompok yang membahas pilihan ksusus program studi sesuai dengan rencana karir, kelompok latihan keterampilan dan kegiatan ekstrakulikuler atau magang yang diadakan sekolah atau lembaga kerja.

Pada siswa yang mengalami masalah belajar, seperti keterlambatan akademik, ketercepatan belajar, sangat lembat belajar, kurang motivasi belajar secara bersikap dan berkebiasaan belajar buruk maka diperlukan bimbingan belajar. Masalah-masalah tersebut dapat diidentifikasi melalui sejumlah cara, yaitu dengan pengadministrasian tes hasil belajar, tes kemampuan dasar, tes diagsnostik, analisis hasil belajar atau karya, dan pengungkapan silap dan hasi belajar. Upaya penanganan masalah belajar itu dilakukandengan sejumlah layanan, antara lain pengajaran perbaikan, kegiatan pengayaan, peningkatan motivasi, sikap dan kebiasaan belajar. Semua layanan itu sangat memerukan kerja sama antara konselor, guru dan personil sekolah lainnya.

Konseling program merupakan layanan yang amat khas, yaitu komunikasi langsung tatap muka antara konseli dan konselor. Layanan khas ini sering dianggap sebagai "jantung hatinya" pelayanan bimbingan dan konseling secara keseluruhan. Layanan konseling perseorangan juga diberi sifat "resmi" dalam arti bahwa layanan ini merupakan usaha yang disengaja dengan niat yang mantap, memiliki tujuan untuk kepentingan dan kebahagian konseli.

Layanan bimbingan dan konseling kelompok memberikan kekhususan tersendiri terhadap pelayanan bimbingan dan koneling secara keseluruhan. Layanan kelompok memiliki beberapa keunggulan, selain lebih efisien dan ekonomis, dinamika interaksi sosial yang terjadi di dalam kelompok juga memberikan warna khas yang tidak tejadi pada konseling perseorangan. Di samping itu konseling kelompok di satu sisi dapat menjadi lahan penjajgaan bagi pelaksanaan konseling perorangan untuk konseli tertentu, di sisi lain menjadi lahan pengembangan keterampilan berkomunikasi dan berinteraksi sosial.

Pelaksanaan berbagai layanan tersebut perlu ditunjang oleh sejumlah kegiatan. Instrumentasi bimbingan dan konseling dengan menggunakan berbagai teknik tes dan nontes yang dapat dikembangkan oleh konselor. Penggunaan instrumen ini di tambah dengan 
sejumlah prosedur lainnya diantaranya, pengamatan, wawancara, dan pengumpulan bahan akan menghasilkan berbagai data, baik data pribadi, data umum, maupun data kelompok,

Kegiatan penunjang lain yang cukup penting adalah konferensi kasus, kunjungan rumah, dan penyelenggaraan alih tangan. Masing-masing kegiatan tersebut memiliki kegiatan dan pola pelaksanaannya sendiri yang kesemuanya tidak lain untuk meningkatkan penyelenggaraan dan keberhasilan segenap fungsi pelayanan bimbingan dan konseling(Sukardi, 2000).

Dalam Permendiknas Nomor16 Tahun 2009, tentang Jabatan Fungsional Guru dan Angka Kreditnya yang menyebutkan bahwa konselor juga sebagai guru, bahwasanya dalam menangani atau proses pembelajaran mengampu sebanyak 150 siswa dan tugas guru bimbingan konseling. Sedangkan untuk waktu pembelajarnnya pada Permendikbud Nomor 18A Tahun 2013 tentang Implementasi Kurikulum pada lampiran IV, ini menjelaskan secara detail tentang implementasi penyelenggaraan bimbingan konseling di sekolah seperti jenis pelayanan, format layanan, kewajiban masuk kelas 2 jam perminggu/rombongan belajar dan sebagainya.

\section{d. Media Bimbingan dan Konseling}

Media layanan dalam bimbingan dan konseling adalah segala sesuatu yang dapat digunakan untuk menyalurkan pesan atau informasi dari pembimbing atau konselor kepada konsli yang dapa meangsang pikiran perasaan, perhatian dan minat sehingga individu akan mengalami perubahan sikap, perilaku atau perbuatan ke arah yang lebih baik.

Adapun dalam pemilihan media bimbingan dan konseling ada beberapa hal yang perlu di perhatikan antara lain:

a. Menyesuaikan bidang layanan.

b. Menyesuaikan tujuan pemberian layanan.

c. Menyesuaikan karakteristik sasaran yang dituju.

d. Menyesuaikan jenis rangsangan untuk perubahan perilaku yang diinginkan.

e. Menyesuaikan keadaan latar belakang sekolah dan lingkungan.

f. Menyesuaikan kondisi siswa.

g. Menyesuaikan biaya, dan lain-lain

Ada beberapa macam media layanan bimbingan dan konseling yang dapat dikembangakan yaitu, film, papan bimbingan, permainan, pohon karir, pohon harapan, dan lain-lain(Nursalim, 2013).

\section{Simpulan Dan Saran}

Gambaran Profil Bimbingan Konseling SMP IT Abu-Bakar Yogyakarta dan SMP Taman Dewasa Ibu Pawiatan Yogyakarta dapat kita lihat dengan terpenuhinya layanan bimbingan konseling, baik itu bimbingan kelompok, bimbingan karir, bimbingan pribadi, dan bimbingan sosial dalam proses pengembangan minat bakat kepada siswa yang ada sekolah tersebut. Pelaksanaan program BK Karir di SMP IT Abu Bakar kami nilai hal tersebut cukup baik bagi perkembangan siswa dimulai dengan pengukuran minat bakat SMP IT Abu Bakar menggunakan alat tes AMT untuk mengukur minat bakat siswa. Pengarahan bimbingan konseling kariri di SMP IT Abu Bakar dibagi tingkatanya untuk kelas 7 dan 8 lebih mengarah beberapa kegiatan ekstrakulikuler dan study club, dan untuk yang kelas 9 lebih kearah keorganisasian dan mengenal sekolah tingkat selanjutnya yakni sekolah menengah atas dan berbagai jurusan yang berada di SMA, ataupun SMK.

Adapun juga Program BK karir di SMP Taman Dewasa Ibu Pawiyatan diantaranya program harian, mingguan, dan bulanan. Untuk program harian sulit terperinci, terbatas dalam pelaksanaannya. Program mingguan yakni ekstrakulikuler yang terdiri dari ektrakulikuler 
wajib untuk siswa laki-laki pencak silat dan untuk wajib untuk perempuan yakni tari. Selain itu, ektrakulikuler pilihan lainnya yaitu paduan suara dan gamelan.

Saran

1. Dalam melihat perbedaan program bimbingan konseling hal ini menujukkan adanya perbedaan dari segi layan bimbingan konseling karir, karena dari kedua sekolah ini masing masing memiliki cirri khsa. Seperti halnya SMP IT Abu Bakar adalah sekolah Islam terpadu yang memadukan nilai nilai keIslaman dalam pembibmbingan dan pengembangan karir bagi siswa. Sedangkan SMP Taman Dewasa adalah sekolah swasta yang berda di bawah naungan yayasan Taman Siswa Yogyakarta yang juga mempunyai cirri khas dari pengembangan karir terhadap siswa dalam menunjang prestasi untuk karir yang lebih baik. Maka dari itu diharapkan kedepannya dapat lebih meningkatkan program layanan bimbingan karirnya dengan pengintekrasian bakat minat sisiwa dalam memilih karirnya agar sesuai dengan minat dan bakatnya.

2. Mengingat berbagai keterbatasan dan kelemahan dalam penelitian ini, maka bagi para peneliti yang berminat untuk mengkaji masalah bimbingan konseing karir ini, perlu lebih mengembangkan lagi dalam mengkaji bimbingan konseling karir yang ada di tiap sekolah mengenai layanan bimbingan konseling karir serta program bimbingan karir, khusnya sekolah menengah pertama dalam pembinaan karir peserta didik untuk selektif dalam memilih sekolah dan karirnya untuk masa yang akan datang.

\section{Daftar Pustaka}

Dalil, S. (2002). Paradigma Baru Manajemen Sumber Daya Manusia. Yogyakarta: STIE YKPN.

Lexy, J. M. (1995). Metodologi Penelitian Kualitatif. Bandung: Remaja Rosdaya Karya.

Marliyah, L., Dewi, F., \& Suyasa. (2004). Persepsi Terhadap Dukungan Orang Tua dan Pembuatan Keputusan Karir Remaja. Jurnal Provitae, 1(1).

Moleong, L. J. (1994). Metode Penelitian Kualitatif. bandung: Remaja Rosdakarya Offset.

Nurihsan, A. J. (2011). Bimbingan dan Konseling dalam Berbagai Latar Kehidupan. Bandung: PT Refika Aditama.

Nursalim, M. (2010). Bimbingan dan Konseling Pribadi-Sosial. Yogakarta: Ladang Kata.

Nursalim, M. (2013). Pengembangn Media Bimbingan dan Konseling,. Yogyakarta: Indeks.

Prayitno. (2008). Trylogy Profesi Konselor. Makalah Disampaikan dalam Seminar Nasional BK, UNP.

Rahma, U. (2010). Bimbingan Karir Siswa. Malang: UIN-Maliki Press.

Sukardi. (2007). Metodologi Penelitian Kompetensi dan Prakteknya. Jakarta: Bumi Aksara.

Sukardi, D. K. (2000). Pengantar Pelaksanaan Program Bimbingan dan Konseling di Sekolah, . Jakarta: PT Rineka Cipta.

Winkel, W. S. S. J. (1997). Bimbingan dan Konseling di Institusi Pendidikan. Jakarta: Grapindo.

Yusuf LN, S., \& Nurihsan, J. (2010). Landasan Bimbingan dan Konseling. Bandung: PT Remaja Rodayakarya. 